\title{
The Effect of Weekend on Mortality Rate in Kut City
}

\author{
Saad Abid Farhan Al-Badri* \\ *Wasit University / College of Medicine / Department of Medicine
}

\begin{abstract}
Background: Several authors suggested that weekend mortality rate is higher than that of other days of the week; on the contrary many authors refuse this suggestion and stated that there is no significant impact of the weekend on mortality rate.
\end{abstract}

Objective: To study the impact of weekend on mortality rate.

Patients, Materials and Methods: The present study was carried out in Al-Karama and AL-Zahraa hospitals in Kut city by reviewing records regarding mortality throughout the period extending from January 2015 through December 2015. Data were classified into the following categories: number of patients admitted on weekend and died in the hospital at any day versus the number of patients admitted on weekdays and died at any day ; number patients died in the hospital at weekend versus number of patients died at weekdays.

Results: Significant difference in percentage of death was found on week end in comparison to weekdays $(\mathrm{P}=0.007)$, whereas there was no significant association between admission on weekend and percentage of death $(\mathrm{P}=0.111)$.

Conclusion: Weekend witnessed significantly higher percentage of death in comparison to weekdays which is probably due to less staffing and equipment during weekends.

Key words: Week end mortality

\section{Introduction}

There controversial evidences that hospital mortality rate might be higher at the weekend in comparison to the rest of week days. Form one point of view, a large number of studies supports the idea of increasing mortality rate at weekends relative to other days, nevertheless a good number of researches found no significant difference in weekend mortality rate compared to other days of the week. A study done in 2012 of over 14 admissions to English NHS hospitals concluded that patients brought to hospitals on Sundays had a $16 \%$ more rate of death compared to those admitted on Wednesdays ${ }^{(1)}$. Another study investigated 4 million admissions performed in 2010 similarly reported a $10 \%$ higher mortality rate at weekends ${ }^{(2)}$. Added to that another observation, by Dr Foster, of a $24 \%$ higher mortality rate in patients being subjected to routine surgery on Fridays than on other days of the week ${ }^{(2)}$. Moreover a substantial mass of US literatures registered the presence of higher weekend mortality rate compared to other week days; one of these studies included 48,253,968 hospital discharges which found a $15 \%$ 
higher mortality ${ }^{(3)}$, and two others supported this finding (4 and 5).

On the hand several studies reported no significant difference in mortality rate in the weekend in comparison to other days, one such study on 6749 patients in UK and specific to upper-gastrointestinal bleeding problems, supported the absence of such difference in weekend morality rate ${ }^{(6)}$.

Controversy has never been limited to whether there is or there is not an increment in weekend mortality rate, but extended to causes behind this suggested higher mortality rate.

The list of possible reasons are many; for example some authors speculated that although lower staffing levels at the weekend could have an effect, patients with more urgent conditions, those who cannot wait to see a doctor on Monday, are admitted more frequently at the weekend (1). Emergency surgical interventions, with probably more dangerous events, is therefore more frequently done at the weekend than on other weekdays ${ }^{(7)}$. Moreover Mortality rate was also higher in hospitals with fewer nurses and physicians on duty at weekends and these findings led to the suggestion that staffing levels evidently affect weekend mortality ${ }^{(3)}$. Added to that is the observation that the performance of essential diagnostic procedures, like emergency endoscopies (40\% lower) and the fixing of fractures $(10 \%$ lower), is less common at the weekend (3). This might suggest that staff supervision of patients and perhaps even concentration and attention diminish as the weekend approaches, another factor determining higher weekend mortality rates ${ }^{(8)}$.

In England, lower clinical staffing levels in hospitals during the night and at the weekend is well documented ${ }^{(9)}$. Emergency departments only manage to have a consultant presence available during 12 hours of each day for $30 \%$ of the time at weekends as compared to $77 \%$ during weekdays ${ }^{(10)}$.

A further study, investigating staffing levels in England perhaps significantly concluded that it was rather the ratio of nurses to patients that determined the probability of mortality (with regard to stroke patients) than the presence (or absence) of doctors on all 7 days of the week (11)

Aim of the study : to investigate if mortality is higher at weekends in respect to both date of admission and date of death in two of Kut hospitals: Al-Karama and Al-Zahraa.

\section{Patients and methods}

This observational cross sectional study was carried out in two major teaching hospitals, with a capacity of 400 beds for each, in Wasit governorate/Kut province/180 km southeast of Baghdad/Iraq. These were Al-Karama and AL-Zahraa hospitals by reviewing records regarding mortality from January 2015 through December 2015. Data were classified into the following categories: number of patients admitted on weekend and died at any day in the week versus the number of patients admitted on weekdays and died at any day; number 


\section{Email:utjmed@utq.edu.iq}

patients died at weekend in the hospital versus number of patients died at weekdays. The weekend in the two hospitals is only Friday. After collection of data, an excel sheet was prepared and then analysis was
Web Site: https://imed.utq.edu.iq

performed using SPSS version 20. One proportion Z-score test was study the difference in Friday mortality in comparison to other days. The significant level was considered at Pvalue of $\leq \quad 0.05$.

\section{Results}

The results were presented from two points of view, on one hand the percentage of death was considered with respect to day of admission (week end versus week day); on the other hand the percentage of death was considered according to day at which death happened (week end versus week day). For purpose of comparison an ideal percentage for week end "Friday" was suggested to be 1 out of 7 $(14.3 \%)$, so that the comparison will be made with the fixed ratio of $1: 6$; one for Friday and 6 for other days. Figure (1) showed the proportion of dead patients who were admitted on Friday "week end" in the two hospitals enrolled in the present study; the percentage was $15.9 \%$. There was no significant difference in mortality percentage of patients admitted on week end in comparison with that for patients admitted on week days in both Al-Zahraa and Al-Karrama teaching hospitals, $\mathrm{P}=0.206$ and 0.253 , respectively, as shown in table (1). Figure (2) demonstrated the mortality percentage of patients who died on week end in comparison with that for patients who died on week days in both hospitals. The percentage at week end was $17.5 \%$, which is significantly higher than the ideal proposed percentage of $14.3 \%$ $(\mathrm{P}=0.007)$. It was also noticed that mortality percentages were higher in both hospitals than the proposed percentage of $14.3 \%$; the percentages were $16.4 \%$ in Al-Zahraa teaching hospital and $20.8 \%$ in Al-Karama teaching hospital; however significant level was obtained in Al-Karama teaching hospital but not Al-Zahraa teaching hospital, 0.006 versus 0.077 , respectively. Nevertheless, it should be emphasized that a level of 0.077 is very near form the significant level of 0.05 , as shown in table (2). 


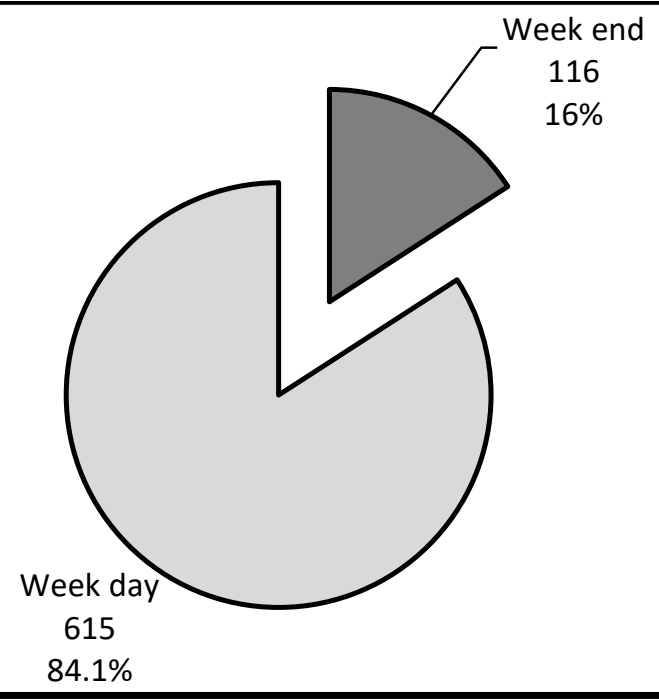

Figure 1: Ratio of Dead patients who were admitted on Friday (Week end)

Table 1: Day at which Patients were admitted to Hospital before Death

\begin{tabular}{|c|c|c|c|c|}
\hline Hospital & $\begin{array}{c}\text { Week end } \\
\text { NO. (\%) }\end{array}$ & $\begin{array}{c}\text { Week day } \\
\text { NO. (\%) }\end{array}$ & $\begin{array}{c}\text { Total } \\
\text { death } \\
\text { NO. (\%) }\end{array}$ & P* \\
\hline $\begin{array}{c}\text { Al-Zahraa Teaching } \\
\text { Hospital }\end{array}$ & $85(15.5)$ & $463(84.5)$ & $548(100.0)$ & 0.206 \\
\hline $\begin{array}{c}\text { Al-Karama Teaching } \\
\text { Hospital }\end{array}$ & $31(16.9)$ & $152(83.1)$ & $183(100.0)$ & 0.153 \\
\hline Total & $116(15.9)$ & $615(84.1)$ & $731(100.0)$ & 0.111 \\
\hline
\end{tabular}

*One Proportion Z -Test Versus (1:6) Ratio

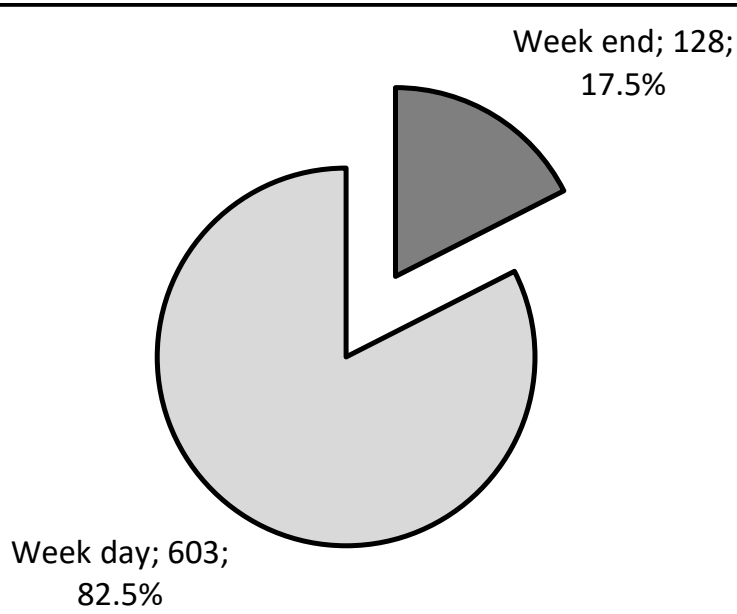

Figure 2: Proportion of Patients who died at Friday (Week end) 
Table 2: Patients who died on Week end

\begin{tabular}{|c|c|c|c|c|}
\hline Hospital & $\begin{array}{c}\text { Week end } \\
\text { NO. }(\%)\end{array}$ & $\begin{array}{c}\text { Week day } \\
\text { NO. }(\%)\end{array}$ & $\begin{array}{c}\text { Total } \\
\text { death } \\
\text { NO. }(\%)\end{array}$ & P* \\
\hline $\begin{array}{c}\text { Al-Zahraa Teaching } \\
\text { Hospital }\end{array}$ & $90(16.4)$ & $458(83.6)$ & $548(100.0)$ & 0.077 \\
\hline $\begin{array}{c}\text { Al-Karamateaching } \\
\text { Hospital }\end{array}$ & $38(20.8)$ & $145(79.2)$ & $183(100.0)$ & 0.006 \\
\hline Total & $128(17.5)$ & $603(82.5)$ & $731(100.0)$ & 0.007 \\
\hline
\end{tabular}

*One Proportion Z -Test Versus (1:6) Ratio

Individual mortality percentages according to hospital units were presented in table (3) for Al-Karma teaching hospital and in table (4) for Al-Zahraa Teaching hospital. Regarding Alkarma teaching hospital, the following results were obtained: mortality percentages of patients admitted on week end was not significantly different from that of patients admitted on week days with exception of surgical department in which the percentage was significantly higher and it was $(29.2 \%) ; \mathrm{P}=0.019$. On the other hand week end mortality percentages were significantly higher than the proposed percentage of $14.3 \%$ in hematology and surgery departments $(\mathrm{P}<0.05)$, while significant difference was not recorded in CCU, medical and pediatric wards ( $\mathrm{P}>0.05$ ). Regarding Al-Zahraa teaching hospital, the following results were recorded: no significant difference was found in mortality percentages of patients admitted on week end in comparison with that of patients admitted on week days $(\mathrm{P}>0.05)$; whereas, significant difference was obtained in weekend mortality percentage in coronary care unit (CCU) only $(\mathrm{P}=0.015)$.

Table 3: Proportion of admitted and Proportion of died patients on week end in AlKarrama Hospital

\begin{tabular}{|c|c|c|c|c|c|c|}
\hline \multirow[t]{2}{*}{ Department } & \multicolumn{3}{|c|}{$\begin{array}{c}\text { Proportion of Death according to Date } \\
\text { of Admission }\end{array}$} & \multicolumn{3}{|c|}{$\begin{array}{l}\text { Proportion of Death according to Date } \\
\text { of Death }\end{array}$} \\
\hline & $\begin{array}{l}\text { Week end } \\
\text { NO. }(\%)\end{array}$ & $\begin{array}{l}\text { Week day } \\
\text { NO. }(\%)\end{array}$ & $\mathbf{P} *$ & $\begin{array}{l}\text { Week end } \\
\text { NO. }(\%)\end{array}$ & $\begin{array}{l}\text { Week Day } \\
\text { NO. }(\%)\end{array}$ & $\mathbf{P} *$ \\
\hline $\mathbf{C C U}$ & 13 (12.9) & $88(87.1)$ & 0.343 & $17(16.8)$ & $84(83.2)$ & 0.233 \\
\hline Medicine & $5(19.2)$ & $21(80.8)$ & 0.236 & $5(19.2)$ & $21(80.8)$ & 0.236 \\
\hline Pediatric & $4(21.1)$ & $15(78.9)$ & 0.200 & $5(26.3)$ & $14(73.7)$ & 0.067 \\
\hline $\begin{array}{l}\text { Haematology } \\
\text { diseases }\end{array}$ & $2(15.4)$ & $11(84.6)$ & 0.455 & $4(30.8)$ & $9(69.2)$ & 0.045 \\
\hline Surgery & 7 (29.2) & $17(70.8)$ & 0.019 & $7(29.2)$ & $17(70.8)$ & 0.019 \\
\hline
\end{tabular}

* One Proportion Z-Test Versus (1:6) Ratio 
Table 4: Proportion of admitted and Proportion of died patients on Week end in AlZahraa Hospital

\begin{tabular}{|c|c|c|c|c|c|c|}
\hline \multirow[t]{2}{*}{ Department } & \multicolumn{3}{|c|}{$\begin{array}{c}\text { Proportion of Death according to Date of } \\
\text { Admission }\end{array}$} & \multicolumn{3}{|c|}{$\begin{array}{c}\text { Proportion of Death according to Date } \\
\text { of Death }\end{array}$} \\
\hline & $\begin{array}{l}\text { Week end } \\
\text { NO. }(\%)\end{array}$ & $\begin{array}{l}\text { Week day } \\
\text { NO. }(\%)\end{array}$ & $\mathbf{P}^{*}$ & $\begin{array}{l}\text { Week end } \\
\text { NO. }(\%)\end{array}$ & $\begin{array}{l}\text { Week day } \\
\text { NO. }(\%)\end{array}$ & $\mathbf{P} *$ \\
\hline $\mathrm{CCU}$ & 37 (17.6) & $173(82.4)$ & 0.084 & $41(19.5)$ & $169(80.5)$ & 0.015 \\
\hline Medicine & $8(20.5)$ & $31(79.5)$ & 0.133 & $4(10.3)$ & $35(89.7)$ & 0.236 \\
\hline Pediatric & $11(12.2)$ & $79(87.8)$ & 0.288 & $13(14.4)$ & 77 (85.6) & 0.483 \\
\hline Premature unit & $19(17.4)$ & 90 (82.6) & 0.174 & $20(18.3)$ & 89 (81.7) & 0.113 \\
\hline RCU & $10(10.0)$ & $90(90.0)$ & 0.111 & $12(12.0)$ & $88(88.0)$ & 0.257 \\
\hline
\end{tabular}

* One Proportion Z -Test Versus (1:6) Ratio

\section{Discussion}

Generally speaking, the result of the present study showed lack of significant association between day of admission and mortality percentage and on the contrary, there was significantly higher percentage of mortality on Friday "week end" in comparison with week days. Specifically speaking, Al-Zahraa teaching hospital witnessed less percentage of weekend mortality than Al-Karama teaching hospital; the week end mortality percentages was significant in hematology and surgical words in Al-Karama teaching hospital whereas it was only significant in CCU ward in Al-Zahrra teaching hospital. In addition, surgical ward of Al-Karama teaching hospital witnessed a significantly higher percentage of mortality for patients admitted on week end in comparison with that for patients admitted on week days while in Al-Zahraa no ward witnessed significant difference in mortality percentage according date of admission.

In agreement with present study, lack of impact of weekend admission on mortality percentage was reported by some authors ${ }^{(17)}$, and disagree with several other authors who reported significant increase in mortality rate for patients admitted on weekends (12-16); however the amount of published literature that support such significant association is far more than that which deny such association. In agreement with present study, some authors reported increase rate of mortality in surgical departments when patients were admitted on weekends (18) and variation in rate according to diagnostic procedures was noticed by others ${ }^{(19)}$.

With regard to higher rate of death in patients admitted to surgical ward on weekends, reported by our study, it may be due to the explanation

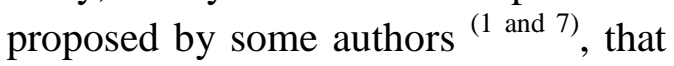
patients factors plays a role in the higher mortality rate during week end, 


\section{Email:utjmed@utq.edu.iq}

such that patients admitted on weekends are more according to emergency rather than elective admission; those patients admitted for an emergency indication, certainly will have higher risk for death than patients admitted electively.

In agreement with the result of the present study that mortality rate is higher by weekends compared to other days of the week, similar findings were noticed by several other researches ${ }^{(6)}$, and disagrees with the finding of other authors ${ }^{(1-5)}$. The proposed explanation for the higher mortality rate during week end in comparison to other week days, regarding our situation, may be due to following possibility: according to the suggestion made by some authors (3, 8-11), that higher weekend mortality is related to low staffing and less medical procedures at weekend, the first impression would be that variation in the quality of medical service by our health institutions during weekend than other days of the week. This does not mean that our health system is optimal, on the contrary we propose that critical and emergency cases almost always seen and managed by junior staff and not by senior staff members, hence there is higher mortality rate during off days than on days of the week.

\section{Conclusions \&}

\section{Recommendations :}

Although most of published literature concentrate on admission to the hospital at weekend and its impact on mortality and in this study no significant impact was found but there is significant increase in percentage of death on weekend so increasing the number of more experienced staff and make more advanced laboratory and radiological investigations readily available is recommended .

\section{References}

1. Freemantle, N., Richardson, M.,et al: Weekend hospitalisation and additional risk of death: An analysis of inpatient data. J R Soc Med.; 105(2): 74-84. 2012

2. Aylin, Yunus, et al: Weekend mortality for emergency admissions. A large, multicentre study. Qual Saf Health Care; 19: 213-217. 2010

3. Ricciardi, R. Nelson,et al:Is the presence of medical trainees associated with increased mortality with weekend admission? BMC Med Educ. ; 14:414.2014

4. Aujesky D, Jiménez D,et al: Weekend Versus Weekday Admission And Mortality Following Acute Pulmonary Embolism. Circulation. ; 119 (7): 962-968. 2009

5. Reeves, M. Smith, et al: Offhour admission and in-hospital stroke case fatality in the get with the guidelines stroke program. Stroke. 40: 596-576. 2009

6. Jairath, Kahan :Mortality From Acute Upper Gastrointestinal Bleeding in the United Kingdom: Does It Display a 'Weekend Effect'? Am J Gastroenterol. ; 106: 1621-1628. 2011

7. Grant, S., Hickley et al: Higher senior staffing levels at weekends and reduced mortality. BMJ. ; 344: 67-73. 2012 


\section{Email:utjmed@utq.edu.iq}

8. Patel R, Thiagarajan P.: Structured approach in improving weekend handovers in a medical high dependency unit. BMJ Quality Improvement Reports. ; 3(1): 205214.2014

9. Goddard, A., Hodgson : Impact of the EWTD on patient:doctor ratios and working practices for junior doctors England and Wales. Clin Med. ; 330-335.2010

10.Gerard WA, Staffer A,et al: Family physicians in emergency medicine: new opportunities and critical challenges. Annals of Family Medicine. ; 8(6):564-565. 2010

11.Bray, B. Ayis, Aet al: Associations between Stroke Mortality and Weekend Working by Stroke Specialist Physicians and Registered Nurses: Prospective Multicentre Cohort Study. PLOS Medicine. ; 11 (8): 13-21.2014

12. Meacock R., Anselmi et al: Higher mortality rates amongst emergency patients admitted to hospital at weekends reflect a lower probability of admission J Health Serv Res Policy. ; 6: 33-41.2016

13. Uematsu H, Kunisawa $S$, et alImpact of weekend admission on inhospital mortality in severe community-acquired pneumonia patients in Japan. Respirology; 21(5): 905-910. 2016.
Web Site: https://imed.utq.edu.iq

14. Mohammed MA, Sidhu KS,et al: Weekend admission to hospital has a higher risk of death in the elective setting than in the emergency setting: a retrospective database study of national health service hospitals in England. BMC Health Services Research; 12: 87-93. 2012

15. Becker, D. J: Do Hospitals Provide Lower Quality Care on Weekends? Health Services Research; 42(4): 1589-1612.(2007)

16. Ricciardi R, Roberts PL,et al: Mortality rate after nonelective hospital admission. Arch Surg; 146:545-551.2011

17. Haddock R., Deighan C. et al:In-patient hospital mortality patterns by day of the week: an analysis of admissions to a regional renal unit. Scott Med. J. ; 26: 123-133.2015

18. Aldridge C, Bion J, et al: Weekend specialist intensity and admission mortality in acute hospital trusts in England: a cross-sectional study. Lancet. ; 388(10040):178186.2016

19. Concha OP, Gallego B, et al: Do variations in hospital mortality patterns after weekend admission.

20. reflect reduced quality of care or different patient cohorts? A population-based study. BMJ Qual Saf. 23(3):215-22.2014 


\section{تاثير عطلة نهاية الاسبوع على معدل الوفيات في مستثفيات الكوت}

سعد عبد فرحان البدري

\section{الخلاصة :}

المقدمة:تختلف الدر اسات الطبية في تاثير عطلة نهاية الاسبوع على معدل الوفيات في المستشفيات فبعض الدر اسات اثبتت و اخرى نفت هذه العلاقة هدف الدر اسة: هو در اسة تاثثير عطلة نهاية الاسبوع في معدل الوفيالت في مستشفيات مدينة الكوت الموارد وطريقة البحث: اجريت هذه الدراسة خلال عام 2015 بعد مر اجعة سجلات المرضى

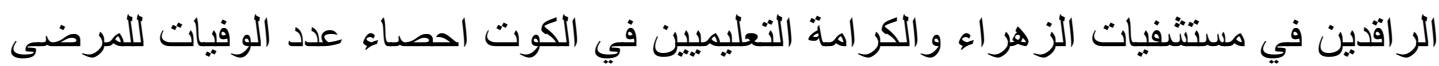
الر اقدين ودر اسة النتائج في محورين فين فرين

المحور الاول: اعداد ونسب المرضى الذين توفوا في عطلة نهاية الاسبوع بغض النظر عن تاريخ

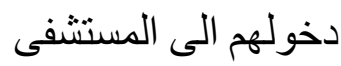
المحور الثاني : اعداد ونسب المرضى الذين ادخلو الى المستشفى في عطلة نهاية الاسبوع وتوفو في اي يوم داخل المستشفى : اعلى

النتائج: اتضح وجود فرق مهم احصائيا في زيادة عدد الوفيات في عطلة نهاية الاسبوع عن باقي الايام , ولم يلاحظ وجود فرق مهم بين يوم الدخول الى المستشفى و اعداد ونسب الوفيات

الاستتناج : ان لعطلة نهاية الاسبوع تاثير في زيادة عدد الوفيات وقد يكون السبب في قلة الكادر

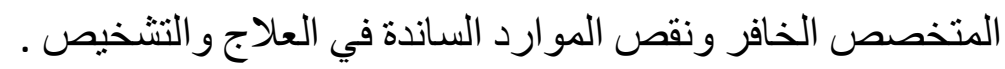

